\title{
Penerapan Model Pembelajaran Kooperatif Tipe TGT dalam Pembelajaran Permainan Bola Besar Berorientasi Sepak Takraw untuk Meningkatkan Kerjasama dan Keterampilan Bermain
}

\author{
Widi Wahyudi ${ }^{1}$, Didin Budiman ${ }^{1}$,Endang Saepudin ${ }^{2}$ \\ ${ }^{1}$ Program Studi Pendidikan Guru Sekolah Dasar Pendidikan Jasmani, Universitas Pendidikan Indonesia \\ ${ }^{2}$ SD Negeri Geger Kalong Girang 1,2 Kota Bandung
}

Info Artikel
.......................................................
SejarahArtikel:
Diterima Januari
Disetujui Maret 2018
Dipublikasikan Mei 2018
Keywords:
keterampilan bermain, kerja sama,
sepak takraw, model kooperatif tipe
TGT

\begin{abstract}
The aim of this study is to find out the impact of Cooperative Learning type TGT on students' cooperation and skill in playing sepak takraw. The method used in this research was classroom action research (PTK) by using GPAI (game performance assestment instrument) observation sheets, field notes, and documentation as the instruments. The participants of the study were 30 fifthgrade students of SDN Gegerkalong 1-2, Bandung. The result of the skill analysis showed the improvement of the initial observation percentage $(15,55 \%)$ to cycle II action II percentage $(75,83 \%)$. Meanwhile, the cooperation test showed that there was improvement on initial observation percentage $(24,44 \%)$ to cycle II action II $(75,56 \%)$. It concludes that the application of cooperative learning model type TGT in sepak takraw could improve students' cooperation and skill in SDN Gegerkalong 1-2 Kota Bandung.
\end{abstract}




\section{PENDAHULUAN}

Zaman Pendidikan, sebagai sarana untuk mengembangkan dan meningkatkan sumber daya manusia yang lebih baik, merupakan pondasi penting bagi kehidupan manusia seutuhnya. Pendidikan berintikan interaksi antara pendidik dengan peserta didik dalam upaya membantu peserta didik menguasai tujuantujuan pendidikan. Interaksi pendidikan dapat berlangsung dalam lingkungan keluarga, sekolah, dan masyarakat. Undang-Undang Nomor 20 Tahun 2003 tentang Sistem Pendidikan Nasional memaparkan bahwa pendidikan di Indonesia terbagi ke dalam tiga jalur utama, yaitu formal, nonformal, dan informal. Pendidikan juga dibagi ke dalam empat jenjang yaitu pendidikan anak usia dini, dasar, menengah, dan tinggi.

Pendidikan, sebagai modal perubahan, harus dimaknai sebagai upaya untuk membantu manusia mencapai realitas diri dengan mengoptimalkan semua potensi kemanusiaan yang dimilikinya. Dengan demikian, proses menuju terwujudnya optimalisasi potensi manusia, tanpa mengenal ruang dan waktu, dikategorikan sebagai kegiatan pendidikan. Hal tersebut menunjukkan bahwa pendidikan tidak hanya terjadi di sekolah, tetapi juga di luar sekolah.

Pendidikan, sebagai upaya untuk menciptakan perubahan ke arah yang lebih baik, menempatkan guru sebagai manusia yang memiliki andil terhadap perubahan sosial. Hal yang paling penting yang harus diperhatikan dalam diri seorang guru yang berperan sebagai faktor fundamental dalam dunia pendidikan adalah sejauh mana guru memiliki kemampuan menciptakan perubahan sosial yang lebih baik. Perubahan yang terjadi bisa dikatakan perubahan sosial jika perubahan itu cukup mempengaruhi struktur sosial, sikap, dan nilai suatu tatanan masyarakat. Perubahan sosial yang lebih baik berarti terwujudnya atau munculnya bangunan atau struktur sosial, sikap, dan nilai yang mencoba memperbaikan atau menyempurnakan keadaan atau tatanan sebelumnya.

Pada kalangan siswa sekolah dasar dan menengah, seperti juga masyarakat pada umumnya, terdapat gejala masalah pribadi dan sosial yang kurang mendukung dalam perilaku keseharian. Di antaranya adalah sikap-sikap individualistis, egoistis, acuh tak acuh, kurang rasa tanggung jawab, malas berkomunikasi dan berinteraksi, rendahnya empati, dan tidak disiplin yang menjadi fenomena yang menunjukkan adanya kehampaan nilai sosial dalam kehidupan sehari-hari. Sesungguhnya, dalam menghadapi kondisi yang demikian, pendidikan dapat memberikan solusi untuk mengatasi masalah sosial sebab pendidikan memiliki fungsi dan peran dalam meningkatkan sumber daya manusia. Sumber daya manusia sendiri dapat menjadi kekuatan utama dalam mengatasi dan memecahkan masalah sosial-ekonomi yang dihadapi, tetapi juga dapat menjadi faktor penyebab munculnya masalah-masalah tersebut.

Pendidikan jasmani sendiri merupakan program dari bagian pendidikan umum yang memberikan kontribusi terhadap perubahan dan perkembangan anak secara menyeluruh. Sehingga, pendidikan jasmani didefinisikan sebagai pendidikan gerak, dan pendidikan melalui gerak, yang harus dilakukan dengan cara-cara yang sesuai dengan konsepnya. Pada praktiknya, pendidikan jasmani yang dilaksanakan memiliki beberapa tujuan. Hal tersebut sejalan dengan pendapat Suherman (2000) tentang klasifikasi tujuan umum pendidikan jasmani 
yang meliputi tujuan perkembangan fisik (physical fitness), perkembangan gerak, perkembangan mental, dan perkembangan sosial.

Dalam proses belajar-mengajar pendidikan jasmani terdapat beberapa aspek yaitu aspek psikomotor, aspek kognitif, dan aspek apektif. Namun, aspek yang paling sentral dalam pendidikan jasmani merupakan aspek psikomotor. Aspek psikomotor merupakan salah satu bentuk belajar yang mempunyai penekanan pada sesuatu yang spesifik, yaitu untuk tujuan meningkatkan kualitas gerak tubuh. Proses belajarnya meliputi pengamatan gerak untuk bisa mengerti prinsip bentuk gerakannya, kemudian menirukan dan mencoba melakukannya berulang kali, untuk selanjutnya menerapkan keterampilan gerak yang dikuasai dalam kondisi tertentu yang dihadapi hingga siswa bisa menciptakan gerakan-gerakan yang lebih efisien untuk menyelesaikan tugas-tugas gerak tertentu. Olahraga permainan sepak takraw di sekolah dasar merupakan salah satu kegiatan belajar dalam pendidikan jasmani untuk mendorong perkembangan keterampilan motorik, kemampuan fisik (psikomotor), pengetahuan dan penalaran (kognitif), serta penghayatan nilai-nilai (sikap-mental-spiritual-sosial).

Lebih jauh lagi, pendidikan jasmani pada hakikatnya adalah proses pendidikan yang memanfaatkan aktivitas fisik untuk menghasilkan perubahan holistik dalam kualitas individu, baik dalam hal fisik, mental, serta emosional. Pendidikan jasmani memperlakukan anak sebagai sebuah kesatuan utuh, makhluk total yang kualitas fisik dan mentalnya saling terpaut. Dengan demikian, pendidikan jasmani memilik beragam manfaat bagi perkembangan siswa.
Manfaat pendidikan jasmani olahraga dan kesehatan di sekolah dasar khususnya mempunyai sasaran dan tujuan untuk membantu para siswa dalam perkembangan fungsifungsi organ tubuh (fisiologis) sebagai upaya peningkatan kesehatan dan kebugaran jasmani, perkembangan psikomotor, perkembangan kognitif, dan perkembangan afektif. Dengan demikian, penulis berpendapat bahwa mata pelajaran pendidikan jasmani merupakan salah satu mata pelajaran yang sangat penting dalam upaya mengembangkan perilaku sosial. Untuk mewujudkan hal tersebut, guru pendidikan jasmani berperan penting dalam merubah perilaku sosial peserta didik.

Pengembangan nilai-nilai dalam olahraga menuntut kemampuan guru dalam memilih dan menggunakan strategi yang tepat dalam pembelajaran pendidikan jasmani agar tujuan yang diharapkan dapat tercapai dengan optimal. Strategi pembelajaran yang efektif dapat dilakukan dengan cara berusaha melibatkan siswa secara tepat dalam materi pembelajaran tertentu, dengan persentase keterlibatan siswa yang tinggi dari waktu yang tersedia melalui pembelajaran yang aktif, kreatif dan menyenangkan, agar siswa lebih antusias dalam mengikuti proses pembelajaran.

Pencapaian tujuan pendidikan jasmani di lapangan cenderung mendapatkan beberapa hambatan, seperti penulis amati dilingkungan SD di Kota Bandung, Khususnya SDN Gegerkalong Girang 1-2, guru pendidikan jasmani lebih menekankan pada pencapaian tujuan perkembangan fisik dan gerak dan cenderung terpaku pada suatu cabang olahraga secara detail. Proses belajar mengajar cenderung hanya menekankan aspek teknik, yaitu penguasaan keterampilan gerak tertentu dengan 
penyampaian informasi, intruksi, dan kegiatan belajar berpusat pada guru. Siswa hanya dipaksa untuk menguasai gerak keterampilan tertentu sehingga aspek lain yang seharusnya dikembangkan terabaikan.

Dampak langsung dari pendekatan tersebut menjadikan siswa cenderung lebih individualistis, kurang menghargai kerjasama, serta berpengaruh terhadap kedisiplinan. Hal ini menyimpang dari tujuan pendidikan jasmani yang diharapkan, yakni selain dalam pengembangan fisik dan gerak juga pengembangan mental dan nilai-nilai sosial.

Berdasarkan hal-hal di atas, nampak bahwa pada satu sisi betapa pentingnya peranan pendidikan jasmani untuk mengembangkan nilai-nilai pendidikan jasmani agar siswa mampu bekerjasama dalam tim, disiplin diri, kerelaan berkorban demi kebaikan tim, kemampuan berpikir, dan menginterprestasikan keseluruhan pengetahuan tentang pendidikan jasmani dalam lingkungannya. Namun, di sisi lain, masih ditemukan kelemahan dalam pembelajaran pendidikan jasmani, baik dalam rancangan maupun dalam proses pembelajarannya. Untuk mengatasi masalah-masalah tersebut, diperlukan penelitian berkaitan dengan pembelajaran pendidikan jasmani yang efektif.

Melalui pembelajaran pendidikan jasmani, secara tidak disadari, mereka akan melakukan suatu proses kerjasama antara siswa yang satu dengan yang lainnya. Hal ini akan semakin terasa jika siswa mendapatkan pembelajaran dengan model pembelajaran yang menuntut siswa untuk bekerjasama. Melalui model pembelajaran kooperatif tipe TGT (Team Games Tournament), siswa akan belajar dengan bekerjasama untuk mendapatkan hasil belajar yang lebih baik.
Di samping itu, permainan sepak takraw merupakan olahraga dinamis dan atraktif karena menuntut suatu kombinasi kemampuan fisik, keterampilan tehnik yang berkualitas, serta kerjasama tim yang baik. Kurangnya nilai kerjasama dalam satu regu merupakan salah satu faktor yang menentukan keberhasilan pembelajaran. Upaya meningkatkan keterampilan dan kerjasama tim bermain sepak takraw harus dilakukan latihan secara sistematis dan kontinyu. Hal mendasar yang harus dikembangkan agar siswa memiliki keterampilan bermain sepak takraw adalah menguasai macam-macam tehnik dasar sepak takraw di antaranya: sepak sila, sepak mula, sepak kuda, sepak badik, sepak cungkil, heading, memaha, mendada, menapak, smash, dan blocking. Berdasarkan pendapat di atas, permainan sepak takraw yang mengarahkan kerjasama tim yang baik, dapat diberikan dengan penerapan model pembelajaran kooperatif tipe TGT (Team Games Tournament).

Pembelajaran kooperatif tipe TGT (Team Games Tournament) merupakan metode pembelajaran dengan siswa bekerja dalam kelompok yang memiliki kemampuan heterogen. Kerjasama sendiri menurut Akbar, dkk (2006) merupakan pembagian kegiatan dalam tugastugas kecil di antara sekelompok orang secara bersama-sama. Bentuk dan pola-pola kerjasama dapat dijumpai pada semua kelompok manusia. Kebiasaan-kebiasaan dan sikap-sikap demikian dimulai sejak masa kanak-kanak di dalam kehidupan keluarga atau kelompok-kelompok kekerabatan. Atas dasar itu, anak tersebut akan menggambarkan bermacam-macam pola kerjasama setelah ia menjadi dewasa. Bentuk kerjasama tersebut berkembang apabila seseorang dapat digerakkan untuk mencapai suatu tujuan 
bersama dan harus ada kesadaran bahwa tujuan tersebut dikemudian hari mempunyai manfaat bagi semua.

Salah satu upaya untuk memecahkan permasalahan tersebut adalah dengan mengembangkan suatu model pembelajaran yang dipandang mampu meningkatkan mental dan sosial siswa. Model pembelajaran yang dianggap mampu meningkatkan perkembangan mental dan sosial siswa adalah model pembelajaran kooperatif. Pada model pembelajaran kooperatif, keberhasilan siswa dalam belajar dapat tercapai melalui belajar kelompok. Pada model pembelajaran kooperatif, tujuan kelompok tidak hanya dalam rangka menyelesaikan tugas yang diberikan, tetapi juga memastikan bahwa setiap kelompok menguasai tugas yang diterimanya. Model pembelajaran kooperatif yang digunakan dalam penelitian ini adalah model pembelajaran kooperatif tipe TGT (Team Games Tournament).

Seperti dikemukakan Slavin (2005), model pembelajaran kooperatif tipe TGT (Team Games Tournament) merupakan suatu model pembelajaran yang dalam pelaksanaannya meliputi komponen pengajaran, belajar tim, dan rekognisi tim.

Model pembelajaran kooperatif tipe TGT (Team Games Tournament) dikembangkan oleh Slavin dan rekan-rekannya, penerapan TGT mirip dengan STAD dalam hal komposisi kelompok, format instruksional, dan lembar kerjanya. Bedanya, jika STAD fokus pada komposisi kelompok berdasarkan kemampuan, ras, etnik, dan gender, maka TGT umumnya fokus hanya pada level kemampuan saja. Selain itu, jika STAD yang digunakan adalah kuis, maka dalam TGT istilah tersebut biasanya berganti menjadi game akademik.
Teknis pelaksanaannya, setiap siswa ditempatkan pada satu kelompok yang terdiri dari siswa yang berkemampuan rendah, sedang, dan tinggi. Dengan demikian, masing-masing kelompok memiliki komposisi yang heterogen. Komposisi ini dicatat dalam tabel khusus (tabel turnamen) yang setiap minggunya harus diubah. Setiap anggota ditugaskan untuk mempelajari materi terlebih dahulu bersama dengan anggotaanggota yang lain, lalu mereka diuji secara individual melalui game akademik. Nilai yang mereka peroleh dari game ini akan menentukan skor kelompok mereka masing-masing.

Melalui pembelajaran kooperatif memungkinkan terciptanya suasana pembelajaran yang komunikatif antara siswa yang satu dengan yang lainnya dan diharapkan dapat membina kemampuan kerjasama siswa (Suherman, 2016). Dalam pembelajaran ini diharapkan siswa dengan kemampuan tinggi mau membantu siswa berkemampuan kurang dan siswa berkemampuan kurang akan merasa diperhatikan sehingga tidak ada perasaan rendah diri atau enggan untuk bergabung dengan siswa berkemampuan tinggi. Dengan demikian, proses pembelajaran lebih interaktif lagi.

Pada penelitian yang dilakukan oleh Setiyawati (2005) dijelaskan bahwa pembelajaran kooperatif berpusat pada siswa dimana peran aktif siswa dan guru dalam menciptakan suatu lingkungan belajar yang kondusif sangat berpengaruh terhadap hasil belajar siswa. Hasil penelitian ini menunjukan bahwa tehnik-tehnik pembelajaran kooperatif lebih unggul dan dapat meningkatkan hasil belajar dibandingkan dengan pengalaman-pengalaman individual atau kompetitif. Berdasarkan hasil penelitian ini, ternyata kompetensi dasar siswa yang mencapai ketuntasan hasil belajar yang mencapai 
$75 \%$ atau lebih besar $82,60 \%$ dengan penelitian mencakup segi kognitif, afektif, maupun psikomotorik. Berdasarkan uraian di atas dan dari hasil penelitian-penelitan sebelumnya, telah terlihat bahwa penerapan pembelajaran kooperatif efektif untuk meningkatkan aktivitas dan hasil belajar siswa. Diharapkan pembelajaran kooperatif tipe TGT (Team Games Tournament) ini dapat meningkatkan hasil belajar siswa terutama dalam menggali dan mengembangkan nilai-nilai sosial dalam hal kerjasama sekaligus keterampilan bermainnya.

Berkaitan dengan pengembangan kemampuan kerjasama siswa melalui model pembelajaran kooperatif tipe TGT yang diintregasikan dalam pendidikan jasmani, penulis mencoba untuk melakukan penelitian mengenai "Penerapan Model Pembelajaran Kooperatif tipe TGT dalam pembelajaran permainan Bola Besar Berorientasi sepak takraw Untuk Meningkatkan kerjasama dan Keterampilan Bermain."

\section{METODE PENELITIAN}

Metode penelitian yang di gunakan dalam penelitian ini adalah metode Penelitian Tindakan Kelas (PTK) atau Classroom Action Research. Seperti yang di kemukakan oleh Subroto, dkk. (2014) penelitian tindakan kelas merupakan sebuah kajian sistematik sebagai upaya peningkatan mutu praktik pembelajaran oleh sekelompok masyarakat melalui tindakan praktis dan refleksi atas hasil tindakan tersebut. Selanjutnya, dikemukakan oleh Susilo, dkk. (dalam Subroto, dkk., 2014) dalam konteks pendidikan jasmani, PTK merupakan penelitian reflektif yang dilaksanakan secara siklis oleh guru atau calon guru pendidikan jasmani, olahraga, dan kesehatan di lapangan atau di ru- angan olahraga dengan tujuan pokok untuk memecahkan masalah-masalah pembelajaran yang dihadapi guru pendidikan jasmani, olahraga, dan kesehatan ketika sedang melaksanakan proses pembelajaran. Dari beberapa pendapat di atas, dapat disimpulkan bahwa penelitian tindakan kelas atau (Classroom Action Research) adalah penelitian tindakan yang dilakukan di suatu kelas untuk meningkatkan dan memperbaiki mutu pembelajaran yang ada di sekolah.

\section{Partisipan dan Tempat Penelitian}

Subjek penelitian dalam PTK ini adalah siswa kelas V SDN Gegerkalong Girang 1-2 Kota Bandung, yang berjumlah 30 siswa (15 siswa laki-laki dan 15 siswa perempuan). Observer/mitra penelitian dalam penelitian ini adalah Endang Saepudin yang juga sebagai guru PJOK di SD Geger Kalong Girang.

\section{Variabel Penelitian}

Variabel adalah gejala yang dijadikan objek pengamatan dalam penelitian. Dalam PTK ada tiga variabel yang akan dikaji yaitu variabel input, variabel proses, dan variabel output. Variabel input dalam penelitian ini adalah siswa kelas V SDN Gegerkalong Girang $1 \& 2$. Variabel proses dalam penelitian ini adalah penerapan model kooperatif tipe TGT. Variabel output dari penelitian ini adalah peningkatan keterampilan bermain sepak takraw dan kerjasama siswa.

\section{Instrumen penilaian}

Instrumen yang digunakan untuk memperoleh data hasil peningkatan kerjasma dan keterampilan bermain sepak takraw memalui penerapan model kooperatif tipe TGT dalam penelitian ini adalah dengan menggunakan instrumen pengamatan GPAI (Game Performance Assessment Instrument) dan Observasi. 


\section{Analisis Data}

Data yang dikumpulkan pada setiap kegiatan observasi dari pelaksanaan siklus penelitian memakai analisis kualitatif dan kuantitatif karena data berupa angka dan berupa kata-kata (narasi) menggunakan presentase untuk melihat kecenderungan yang terjadi dalam proses kegiatan pembelajaran. Proses analisis dimulai dari awal sampai akhir pelaksanaan tindakan. Data yang terkumpul dapat dianalisis dari tahap orientasi sampai tahap akhir dalam pelaksanaan tindakan dengan disesuaikan pada karakteristik, fokus masalah, serta tujuan. Kriteria dan ukuran keberhasilan tujuan penelitian ditentukan berdasarkan hasil evaluasi belajar secara individu

Penulis mengunakan lembar observasi yang diberikan kepada observer, yaitu lembar observasi siswa. Lembar observasi ini berisikan penilaian aspek psikomotor dan afektif, yaitu kerjasama dan keterampilan bermain.

\section{HASIL PENELITIAN}

\section{Perencanaan Pembelajaran}

Perencanaan pembelajaran diawali dengan perumusan tujuan pembelajaran. Perumusan tujuan pembelajaran yang tidak diinformasikan secara jelas kepada siswa menjadi kendala tercapainya target, seperti yang terjadi pada siklus I tindakan I. Selanjutnya diikuti oleh pengkoordinasian. Dalam hal ini, pengelolaan waktu harus diperhatikan secara tepat karena terkait dengan pengelolaan kelas. Hal ini tanpak pada tindakan I siklus I yang mengakibatkan terbuangnya waktu secara percuma. Temuan lain yakni pembagian kolempok belum terencana dengan baik sehingga mengganggu proses belajar mengajar seperti pada tindakan I siklus I dan tindakan II siklus I. Melihat temuan di atas, dapat disimpulkan bahwa prosedur perencanaan sangat menentuakan pencapaian target keberhasilan pembelajaran

\section{Pelaksanaan Pembelajaran}

Berdasarkan hasil penelitian dari mulai observasi awal sampai siklus dua tindakan dua, diketahui peningkatan kerjasama dan keterampilan bermain dalam permainan bola besar berorientasi sepak takraw melalui penerapan model kooperatif tipe TGT. Adapun jika digambarkan dalam bentuk grafik pencapaian kerjasama dan keterampilan bermain dalam permainan bola besar berorientasi sepak, dari mulai observasi awal sampai dengan siklus dua tindakan dua dapat digambarkan sebagai berikut:

\section{Grafik 1}

Grafik Perolehan Nilai Keseluruhan

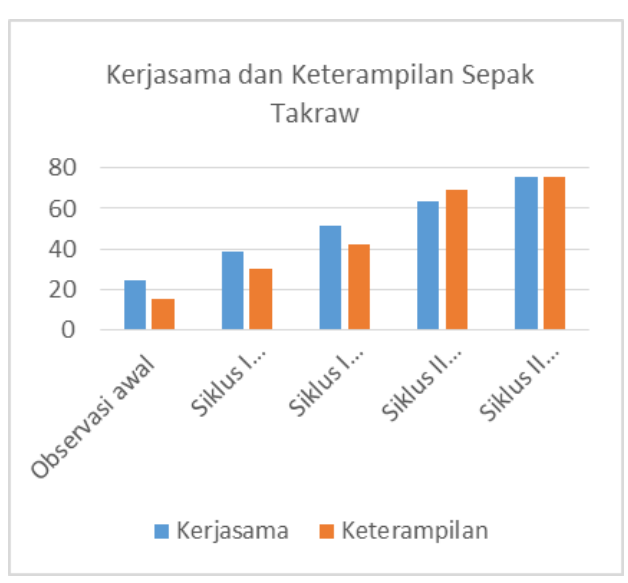

Dari hasil penelitian yang telah dilakukan peneliti dari mulai observasi awal sampai dengan tindakan terakhir, yaitu siklus II tindakan II, didapat data rata-rata persentase keseluruhan data awal adalah kerjasama $24.44 \%$ dan keterampilan $15,55 \%$, siklus I tindakan I adalah kerjasama $38,52 \%$ dan keterampilan $30,27 \%$, siklus I tindakan II adalah kerjasama $51,48 \%$ dan keterampilan 42,50, siklus II tinda- 
kan I adalah kerjasama 63,70\% dan keterampilan $69,16 \%$, dan siklus II tindakan II adalah kerjasama 75,56\% dan keterampilan 75,83\%. Berdasarkan data yang diperoleh dari observasi awal sampai siklus II tindakan dua, dapat diketahui bahwa kerjasama dan keterampilan bermain bola besar berorientasikan sepak takraw kelas V SDN Gegerkalong 1-2 kota Bandung telah meningkat dari nilai rata-rata persentase keseluruhan kerjasama $24.44 \%$ dan keterampilan $15,55 \%$ menjadi kerjasama $75,56 \%$ dan keterampilan bermain sebesar $75,83 \%$.

Pendekatan model kooperatif, menurut Johnson dalam saputra (2007) merupakan pembelajaran kelompok yang terstruktur atau sistem pengajaran gotong royong yang memiliki lima unsur pokok yaitu saling ketergantungan positif, tanggung jawab individu, interaksi personal, keahlian bekerjasama, dan proses kelompok. Model pembelajaran kooperatif tipe TGT belum banyak diterapkan dalam pendidikan. Guru sulit penerapkan system kerjasama di dalam kelas karena beberapa alasan. Alasan yang utama adalah kehawatiran terjadi kekacauan di kelas dan siswa tidak belajar apabila jika ditempatkan dalam kelompok yang tidak sesuai dengan keinginannya. Selain itu, banyak yang menilai kesan negatif mengenai kegiatan kerjasama atau belajar dalam kelompok. Ada juga siswa yang tidak senang disuruh bekerjasama dengan siswa lain. Siswa yang tekun harus bekerja melebihi siswa yang lain dalam kelompoknya, sedangkan siswa yang kurang mampu merasa minder ditempatkan dalam kelompok siswa yang pandai. Siswa yang tekun juga merasa bahwa teman yang kurang mampu hanya menuntut saja pada hasil jerih payah siswa yang pandai.
Dalam penerapan model kooperatif tipe TGT seorang guru harus benar-benar menerapkan prosedur model kooperatif tipe TGT, sehingga pembagian tugas yang tidak adil tidak terjadi dalam kelompok. Model kooperatif tipe TGT tidak sama dengan sekedar belajar dalam kelompok yang dilakukan asal-asalan. Pelaksanaan pembelajaran kooperatif tipe TGT dengan benar-benar akan memungkinkan guru mengelola kelas dengan lebih efektif.

Penerapan model kooperatif tipe TGT dalam pembelajaran sepak takraw di kela V SD Gegerkalong Girang 1-2 Kota Bandung, semula memang sulit diterapkan dan dicerna oleh siswa. Hal tersebut disebabkan karna model kooperatif tipe TGT ini baru mereka dapatkan, sehingga siswa terlihat bingung dalam memahami materi pembelajaran yang diberikan. Setelah diberi tindakan dan evaluasi, siswa mulai memahami tugas yang harus mereka kerjakan. Mereka sangat bersemangat ketika proses belajar-mengajar berlangsung. Sejalan dengan penelitian sebelumnya (Khoiriah, 2016) model pembelajaran kooperatif tipe TGT dalam pembelajaran bola besar berorientasi permainan sepak takraw dapat meningkatkan keterampilan bermain dan kerjasama

\section{KESIMPULAN}

Penerapan model kooperatif tipe TGT dapat menigkatkan kerjasama dan keterampilan bermain sepak takraw siswa kelas V SDN Gegerkalong 1-2 kota Bandung. 


\section{DAFTAR PUSTAKA}

Arywibowo, D. M., \& Prihartanti, N. (2009). Penurunan Berat Badan Pada Obesitas Melalui Pengaturan Diri. Jurnal Penelitian Humaniora, 10(2), 199-211

Abduljabar, B dan Darajat, J .(2012). Aplikasi Statistika dalam Penjas. Bandung: UPI.

Akbar Hawadi Reni, Ikke Anggraeni, Khairunnisa. (2006) Bekerjasama. Kretivitas Untuk Mendorong Anak Suka Bekerja Sama. Jakarta: divisi buku perguruan tinggi.

Arikunto,S.(2002).Prosedur Penelitian: Suatu Pendekatan Praktik. Jakarta: Rineka Cipta.

Hamidi, K (2007), Sepak Takraw. Jakarata

Husdarta dan Saputra, M.Y. (2000) belajar dan pembelajaran. Jakarta: Departemen Pendidikan Nasional, Direktorat Pendidikan Dasar dan Menengah

Huda, M, M. Pd. (2013) Cooperative lerning, motode, teknik, struktur dan model penerapan. Yogyakarta: Pustaka pelajar

Iyakrus, (2012), SepakTakraw, Palembang: UNSRI PRESS.

Johnson, Johnson \& holubec 1993 http:// sutiada.blogspot.co.id/2012/11/v-

behaviorurldefaultvmlo.html Diakses 15 April 2017

Kagan, S (2009) Cooperative learning. San clemente,CA: kagan Publishing

Khoiriah, D. S. (2016). Pengaruh Model Pembelajaran Kooperatif Tipe Team Game Tournament (Tgt) Terhadap Pembentukan NilaiNilai Kerjasama Dalam Pembelajaran Permainan Hoki. JURNAL PENDIDIKAN JASMANI DAN OLAHRAGA, 1(1), 27-37.

Lutan. (2001).Pengukuran dan evaluasi pendidikan jasmani dan kesehatan. Bandung: DEPDIKBUD

Lutan, R. (1998). Pembaharuan proses agogik dan optimalisasi fungsi sosial olahraga dan pendidikan jasmani: sebuah refleksi dalam masa krisis. Pidato pengukuhan janbatan guru besar tetap. Bandung. FPOK IKIP Bandung

Mahendra, A , (2015), Filsafat Pendidikan Jasmani, Bandung : FPOK UPI
Mahendra, A. (2009). Asas dan Falsafah Pendidikan Jasmani. Bandung: FPOK Universitas Pendidikan Indonesia.

Matzler, M. W. (2000). Instructional models for physical education. Georgia State University

Memmert dan Harvey. (2008). The Game Performance Assessment Instrument (GPAI).

Mundakir. (2011). Pengaruh model pembelajaran kooperatif teknik STAD dan jigsaw dalam pendidikan jasmani terhadap pengembangan nilai-nilai sosial. Tesis. Bandung : Universitas Pendidikan Indonesia

Rahmat Subagja 050517 (2012). Pengaruh pendekatan bermain terhadap pembentukan kerjasama (penelitian tindakan kelas Smp pasundan 10 bandung) Bandung.

Slavin, Robert E. (2005), Cooperative Learning, Teori, Riset Dan Praktik, Edisi Terjemahan: Nurlita Yusron. Bandung: Nusa Media

Setiawati, S, (2005), Pembelajaran Kooperatif yang Berorientasi pada pembelajaran untuk meningkatkan hasil belajar siswa...Diakses Maret 2017

Suherman, A. (2009), Revitalisasi Pengajaran dalam Pendidikan Jasmani. Bandung: Bintang Wali Artika.

Suherman, A. (2016). PENGARUH PENERAPAN MODEL KOOPERATIF TIPE JIGSAW DAN TGT (TEAMS GAME TOURNAMENT) TERHADAP KETERAMPILAN SOSIAL DAN KETERAMPILAN BERMAIN BOLAVOLI. JURNAL PENDIDIKAN JASMANI DAN OLAHRAGA, 1(2), 8-15.

Suherman, S. (2000), Dasar-dasar Penjas. Bandung: Depdikbud

Suherman, B, \& Hoenurisa (2013), Indikator Kerjasama, Surabaya

Subroto.T, Yudiana.Y, dan Hidayat.Y.(2014). Pedoman Penelitian Tindakan Kelas Dalam Pendidikan Jasmani, Olahraga, dan Kesehatan. Bandung:FPOK Universitas pendidikan Indonesia.

Sugiyono, (2006/2009). Metode Penelitian Pendidikan.Bandung: Alfabeta 